\title{
EL POETA CIEGO DE GUANAJUATO
}

La ciudad de Guanajuato vio nacer, el 4 de julio de 1838, a uno de los poetas románticos más interesantes dentro de nuestra literatura, pero también el que menos ha sido estudiado por los criticos e historiadores. Juan Valle fue un sincero y fiel exponente de ese género que vino al mundo con Werther y murió enganchado en la punta de los mostachos del "Duque Job": el romanticismo. Las circunstancias que rodearon la vida de Valle lo hicieron ser aún más romántico que sus contemporáneos, es decir, más triste, más sombrio, más fatalista. A los cuatro años de edad es atacado por una enfermedad en los ojos y a pesar "de los esfuerzos de su familia y de la ciencia para devolverle la vista", como dijo Francisco Zarco, quedó ciego para siempre.

Mas también, por mi desgracia, presto ciego me quedé, todo lo que habia visto sintiendo doble no ver.

La madre del poeta y su hermano Ignacio se convirtieron en sus guías y pasaban largas horas junto al niño y luego junto al adolescente leyendo en voz alta cuanto libro podían conseguir, desde la Biblia y los clásicos griegos, hasta los autores mexicanos, sin olvidar la novelística y la poesia española de los siglos de oro. El joven ciego era poseedor de una memoria privilegiada y de una gran sensibilidad, lo que le ayudaba a asimilar con una sola vez que las escuchaba, las principales ideas, conceptos e influencias que después vertería en largos poemas. Hasta los catorce años, los temas de su producción, que dictaba al paciente Ignacio, eran bíblicos -a Eva, a Moisés, a David-, o bien clásicos -Espartaco, el incendio de Roma, Grecia-, pero esta primera etapa carece de importancia porque la influencia de Manuel Carpio es tan sensible que sólo se disculpa por la juventud del poeta ciego. Sin embargo, al recibir otro golpe de la vida que lo deja huérfano de madre, Juan Valle adquiere un estilo y se lanza de lleno en la corriente romántica:

Tuve una madre, tuve, no la tengo, que en fatal, inolvidable día, de Dios sedienta, en su último suspiro me dejo su postrera despedida. 
Cuando el tiempo hubo calmado el dolor de la pérdida, y la naturaleza le recordó que era hombre y que como tal debía amar y ser amado, fija su mente y sus oidos en la dulce voz de una amiga de la casa, María de Jesús Camiña, y cree enamorarse de ella. Fue un amor de adolescente romántico, platónico, lucubrado, sin ninguna probabilidad de ser correspondido, pero Valle se entrega a sus ensueños llenos de pasión y dicta sus poemas iniciales sobre el amor:

Entraron en amable competencia la Dicha y el Amor cuando te hallaron, y que eras toda suya proclamaron; mas a un tiempo los dos con preferencia:

"Mía es, dijo la Dicha: su existencia mis cadenas de rosa cautivaron", "Es un ángel que los cielos me legaron, -dijo el Amor-, me toca por herencia."

Pero María de Jesús quiere a otro y pronto contrae matrimonio. E1 poeta ciego en el fondo se siente feliz con este desengaño, porque asf puede volver a quejarse y a sentirse un ser desdichado:

EI infortunio aliado con la suerte ya nos separa bárbaro a los dos... |ay!, tu partida me herirá de muerte, es mi sentencia tu postrer adiós.

Pronto se consuela y se enamora de Guadalupe Medina, pero en esta ocasión el poeta es sincero en su sentimiento, porque la joven llega a corresponderle con ligeros cariños y palabras dulces que seguramente eran más de compasión que amorosas, pero que a Juan lo transportan de júbilo y lo hacen soñar en la felicidad.

Te alzaste sobre la tumba

de mis muertas ilusiones, cual se alza en los panteones consoladora una cruz.

Tú eres la palma clemente que en un yermo se levanta, por eso mi voz te canta: ¿Bendita mil veces tú! 
Guadalupe lo deja bien pronto y el poeta llora en sus poemas su tristeza. Cree enamorarse tres veces más hasta que al fin, a los veinticuatro años, encuentra el verdadero amor en Josefa Aguilar, la que se convierte en su esposa y lo hace padre de una niña. El poeta ciego es feliz, pero por poco tiempo, ya que dos años después, en 1864, muere dulcemente en brazos de Josefa.

Su producción poética es grande y en ella encontramos hermosos cantos a los héroes de la patria, como el dedicado a Cuauhtémoc, figura que le inspiró siempre un profundo respeto:

Mas Ia envidiosa muerte, que ha borrado los nombres de cien pueblos y cien reyes, borrar no pudo tan glorioso nombre, $y$, del olvido a las tremendas leyes no viéndote sujeto, ella conoce que tú eres más que un hombre.

Dicta poemas dedicados a sus amigos y colegas, como Ignacio Rodrguez Galván, Isabel Prieto de Landázuri, Guillermo Prieto, Francisco Zarco, José María Vigil, al compositor Cenobio Paniagua, al pintor Juan Cordero, y al maestro de todos los escritores y artistas mexicanos del siglo xix, Ignacio Manuel Altamirano. Pero es el poeta Juan Díaz Covarrubias quien inspira a Valle una ternura especial, y cuando aquel novelista y poeta cae asesinado en la masacre de Tacubaya en 1859, el cantor ciego recuerda con tristeza la flor predilecta de Covarrubias, la sensitiva, que sería el símbolo del romanticismo:

Con pecho filantrópico preñado de cariño, con voluntad enérgica y corazón de niño, con un pensar volcánico, con alma femenil, carácter tierno y tímido cual frágil sensitiva, al par que noble y sólido como la encina altiva, la gloria honró su lápida con su inmortal buril.

Al estallar la guerra de Reforma, Juan Valle se declara defensor ardiente de esa causa, y en el diario El Siglo $X I X$ que dirigia Zarco, 
el poeta ataca duramente a los enemigos de la Reforma. Por ello, cuando el partido conservador toma la ciudad de Guanajuato, el ciego es sacado a empellones de su casa y paseado por las calles en medio de insultos y golpes. Luego es enviado a la cárcel donde permanece algunos meses y en ella escribe un Himno a la libertad que comienza:

Mi alma inmortal su libertad pregona, aunque preso $\mathrm{mi}$ cuerpo siento yo;

la prisión que a mi cuerpo así aprisiona cadenas para el alma aún no inventó.

Luego es desterrado de su Estado natal y se refugia en Morelia y en Guadalajara, hasta que Benito Juárez y González Ortega hacen triunfar la causa de la Reforma y Valle regresa a su amado Guanajuato y dicta entusiasta:

¡Grande Juárez, salud! Tú generoso

la gran revolución intacta y bella

has conducido a un término glorioso, como al lecho conduce de su esposo, pura, su padre a la gentil doncella.

Es de desear que algún historiador o crítico literario examinase con detenimiento la obra de este poeta guanajuatense, símbolo del romanticismo en México, y cuya vida es también reflejo fiel de una época literaria y de un momento histórico lleno de interés. Juan Valle, el poeta ciego, verá realizado su sueño que dictó dos años antes de morir:

Anhelo lleguen a mi ansioso ofdo

los aplausos de inmensa multitud;

y viva de mi cítara el sonido

cuando yo duerma en fúnebre ataúd.

Poestas de Juan Valle. 717 pp. México.

Imprenta de Ignacio Cumplido. 1862. 